\title{
XXV. On a means of detecting kinic acid
}

\section{John Stenhouse Ph.D.}

To cite this article: John Stenhouse Ph.D. (1845) XXV. On a means of detecting kinic acid , Philosophical Magazine Series 3, 26:172, 198-199, DOI: 10.1080/14786444508645104

To link to this article: http://dx.doi.org/10.1080/14786444508645104

$$
\text { 册 Published online: } 30 \text { Apr } 2009 .
$$

Submit your article to this journal

Џ Article views: 2

Q View related articles $₫$ 
198 Dr. Stenhouse on a means of detecting Kinic Acid.

appears to baffle our present information on the localities of these deposits. I have been lately thrown into a train of communication frorn which I have gained some curious information, which may, to a certain extent, assist in elucidating the point. It appears that the seal-fishers have for a long series of years been in the constant habit of frequenting this island, Ichaboe, as a convenient spot for the purpose of extracting the oil from the fat of the seals which they may have caught; and this is effected by melting the fat over a wood fire, the fuel for the purpose being collected on the island, the carcases of the seals being thrown aside as useless, and becoming the food of the innumerable sea birds frequenting the district, and thus giving rise to the deposit of the guano on, or in close proximity to, the spot where the ashes of the wood fires and the bodies of the seals had been left; and hence we may, to a certain extent, argue on the source of the potash and its decomposing the ammoniacal salts existent in the putrefying carcases or the deposit of the birds. It will also account for the frequent occurrence of the skin and bones of the seal as observed in nuch of the imported guano.

XXV. On a means of detecting Kinic Acid. By John Stenhouse, Ph.D.*

THOUGH kinic acid does not possess any very striking characters by which it can be easily recognised, its presence may be readily collected by converting it into that very remarkable product of its decomposition, kinone. As there is good reason for believing that kinic acid exists in the state of kinate of lime in all the barks which contain the alkaloids quinine and cinchonine, it may perhaps be of some importance to describe an easy mode of detecting kinic acid, as this may facilitate the discrimination of the true cinchona barks from the spurious ones.

To examine a bark for kinic acid, it is merely necessary to boil a little of it, say a quarter of an ounce, with a slight excess of lime. The liquor may be poured off and concentrated, as it is not necessary to flter it. It is then to be introduced into a retort and distilled with a mixture of half its weight of sulphuric acid and peroxide of manganese. If the bark contains the smallest quantity of kinic acid, the first portion of the liquid which distils over has a yellow colour and the very peculiar smell of kinone. If the liquid is treated with a little ammonia, it immediately becomes of a deep brown colour, which in a few minutes changes to brownish black; or if a little chlorine water is added to a second portion of the liquid,

* Communicated by the Chemical Society; having been read Decenber 2, 1844 . 
it changes from a yellow to a bright green colour. The distillation need not be long continued, as the kinone is very volatile, and comes nearly all over at the first. I have tried this experiment with the genuine barks China rubra, China loxa, and China regia, and detected the kinic acid very readily, when less than a quarter of an ounce of each was employed. I have also operated on two ounces of the false bark, China nova Surinamensis, but was unable to detect the least trace of kinic acid.

It has long been stated in most systems of chemistry, on the authority of Berzelius, that the alburnum of Pinus sylvestris contains a half per cent. of kinate of lime, and that kinic acid exists along with gallic acid in the barks of various other trees. A pound and a half of the inner bark and alburnum of the Pinus sylvestris was treated in the way already described, but I was unable to detect any trace of kinic acid; though on adding less than two grains of kinate of lime the presence of kinone in the liquid which distilled over was immediately perceptible.

I may state, in conclusion, that the presence of the vegetable alkaloids quinine or cinchonine in a bark may be readily detected by the following simple experiment. Macerate the bark with dilute sulphuric acid and precipitate with a slight excess of carbonate of soda or potash. Collect the dark-coloured, very impure precipitate, and distil it with a great excess of caustic soda or potash, cincholin will distil over in oily drops if the bark has contained either of these vegetable alkaloids. Cincholin is easily recognisable by its peculiar taste and smell and its strongly-marked alkaline properties. It is nearly insoluble in water, unless first neutralized by an acid, when it readily dissolves; but it is immediately reprecipitated in oily drops on the addition of an alkali. It is quite true that the production of cincholin is not a decisive proof that a bark must necessarily contain quinine or cinchonine, as other alkaloids, such for instance as strychnine, also yield it when distilled with potash. The production of cincholin, however, clearly indicates the existence of at least one alkaloid in the bark, the exact nature of which may be subsequently ascertained by the usual methods.

XXVI. Remarks upon Chloranil.

By Augustus William Hofmann, Ph.D.*

FRMANN , in his researches upon the action of chlorine on indigo, obtained, as the last product of this reaction, a

* Communicated by the Chemical Society; having been read December 2,1844 .

$\dagger$ Journ. für Prakt. Chem., Bd, xxii. S.279. [Phil. Mag. S. 3, vol, xix. p. 192.] 